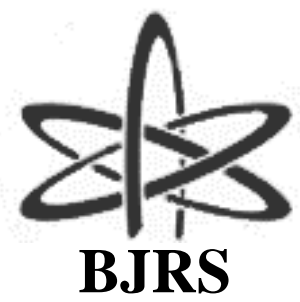

\author{
BRAZILIAN JOURNAL \\ $\mathrm{OF}$ \\ RADIATION SCIENCES \\ 06-02 (2018) 01-22
}

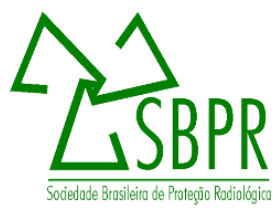

\title{
Dose estimation and calculation of radiological hazard index at Doce River / Brazil due to Fundão dam rupture
}

\author{
R.F. Carmo $;$; H. Evangelista ${ }^{\text {b }}$ J.U. Delgado ${ }^{\text {a }}$ O.L.Trindade Filho ${ }^{\text {a }}$ A.V. Flores ${ }^{c}$ \\ J.N. Ribeiro ${ }^{\text {d. M.G. Pereira }}{ }^{\mathrm{e}}$; M.V. Licinio ${ }^{\mathrm{d}}$ \\ a'Instituto de Radioproteção e Dosimetria (IRD)/Comissão Nacional de Energia Nuclear (CNEN). \\ Av. Salvador Allende, s/n $n^{o}$ Barra da Tijuca, 22783-127, Rio de Janeiro, RJ, Brasil \\ ${ }^{b}$ Laboratório de Radioecologia e Mudanças Globais (LARAMG)/Universidade do Estado do Rio de Janeiro \\ Rua São Francisco Xavier, 524. Maracanã, 20550-013, Rio de Janeiro, RJ, Brasil. \\ ${ }^{c}$ Instituto Federal do Espírito Santo (IFES), Vitória, ES, Brasil. \\ ${ }^{d}$ Laboratório de Bioquímica e Biofísica Ambiental (LBBA)/Universidade Federal do Espírito Santo \\ Av. Marechal Rocha Campos, 1468, Maruípe, 29043-900, Vitória, ES, Brasil. \\ ${ }^{e}$ Departamento de Ciências Exatas e da Terra, Universidade do Estado da Bahia, Bahia, Brasil \\ rfcarmo@bolsista.ird.gov.br
}

\begin{abstract}
Radionuclide activity monitoring of the natural occurrence of ${ }^{226} \mathrm{Ra},{ }^{228} \mathrm{Ra}$ and ${ }^{40} \mathrm{~K}$ is important in order to assess the radiological impact and human exposure due to natural radioactivity. Surface concentrations of these radionuclides may change due to soil use, urbanization or deforestation. In November 2015, a rupture of a tailings dam in the upper course of Doce River, in the Southeastern part of Brazil, caused a catastrophic environmental hazard -the greatest accident in a mineral area in the Southern Hemisphere. In this work, we developed a prospective evaluation of radioactivity levels in sediments of the Doce River obtained from its estuary before and after the dam rupture. Activities were analyzed by high resolution gamma spectrometry for ${ }^{226} \mathrm{Ra},{ }^{228} \mathrm{Ra}$ and ${ }^{40} \mathrm{~K}$. Results ranged from $15.86 \pm 0.99,19.83 \pm 1.10$ and $237.15 \pm 8.70 \mathrm{~Bq} \cdot \mathrm{kg}^{-1}$ for before the rupture and $20.70 \pm 0.99,31.82 \pm 1.30$ and $197.50 \pm 7.62 \mathrm{~Bq} \cdot \mathrm{kg}^{-1}$ for the period after, respectively. This study identified a significant elevation of ${ }^{226} \mathrm{Ra},{ }^{228} \mathrm{Ra}$ activities after the rupture. We also evaluated the annual effective dose equivalent to the local population and the radiological risk index, both internally and externally. The results obtained for the radiological risk to the local population were compared with world wide values.
\end{abstract}

Keywords: Doce River, dam of Fundão, radiological risk, NORM, natural radioactivity. 


\section{INTRODUCTION}

Estuaries are water bodies of prime importance to biodiversity, due to their high content of nutrients and organic matter, being the natural habitat of several species of birds, mammals, crustaceans, chelonians and fish. Therefore they are places of value for commerce, recreation and migratory bird routes $[1 ; 2]$. Due to fast-growing populations in coastal cities, these environments are under great pressure because, among various activities, they are used for access to the interior of the continent, for urban mobility and for sand extraction -if they are not protected by federal laws.

The Doce River basin is an important hydrological system in southeast Brazil with a drainage area of $83,400 \mathrm{~km}^{2}$ that includes a total of 222 districts. Parts of the mining activities of Samarco Mining S.A./Vale S.A. and BHP Billiton are related to this basin and they are responsible for the management of the natural deposits of ores and iron ore processed from the mineral province of the Mariana region, State of Minas Gerais. A part of this material is stocked at the Fundão dam. On November 5th, 2015, a partial rupture of the dam occurred, discharging huge amounts of tailings into the Doce River. This event released about 50-60 million $\mathrm{m}^{3}$ of tailings into the Gualaxo do Norte River, devastating almost completely the District of Bento Rodrigues and causing impacts on water quality, turbidity and heavy-metal remobilization from the riverbed on about $680 \mathrm{~km}$ of the Gualaxo do Norte, Carmo and Doce Rivers and the estuarine region by the sea. The plume of sediments reached the coastal zones surrounding the mouth of the Doce River on the Atlantic Ocean, with an extension of tens of kilometers. The tailings wave destroyed a small district along its way (Figure 1), advanced on protected areas and changed significantly the water turbidity, imposing a great loss on aquatic biodiversity. This disaster has not only significantly impacted the environment and the local economy but also the communities' social routine as the Doce River estuary region had been used by the local population, especially in the dry season, as a land means of transport. 
Figure 1: View of the Fundão tailings dam and Bento Rodrigues district (a) before and (b) after the rupture; (c) location of the mouth of the Doce River; (d) estuarine and sediment plume area on the coast.
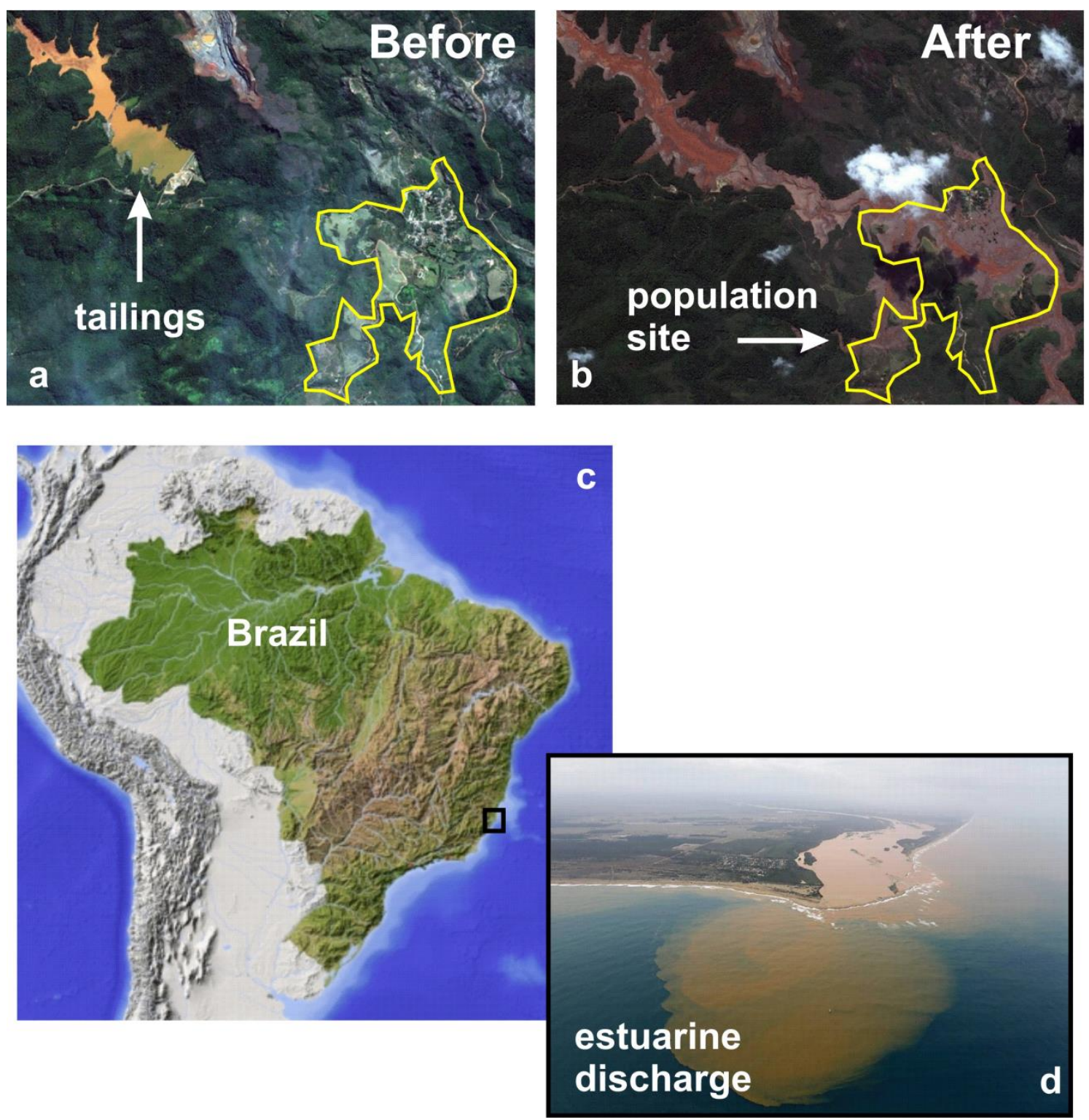

The intense flow of tailings in the Doce River in the days that followed the dam rupture exposed not only the minerals that once existed inside the dam (predominantly $\mathrm{Si}, \mathrm{Fe}$ and $\mathrm{Mn}$ ), but also heavy metals (As, $\mathrm{Cu}$ and $\mathrm{Cd}$ ) from agriculture and industry, land use and small-scale milling activities that for decades were dumped into the river substrata [3]. It is known that the northern 
region of the State of Rio de Janeiro, Espírito Santo State and the northeastern coast present anomalies of the mineral monazite, phosphate-containing metals and rare earths -an important source of thorium, lanthanum and cerium [4]. Their regional occurrence involves the presence of thorium in significant concentrations. Early low-scale monazite mining does not have a fully described history of tailings discharge and probably has taken part in effluent flow into the Doce River. Naturally occurring radionuclide materials are mentioned in the literature as NORM. These, when in high concentrations, expose humans to the risk of ionizing radiation effects [5].

The present study aims to carry out a prospective analysis on the presence of NORM in sediment samples of the Doce River estuary before and after the arrival of sediments containing mining tailings, and to estimate the risk exposure of the population, from the determination of sediment activities of ${ }^{226} \mathrm{Ra},{ }^{228} \mathrm{Ra}$ and ${ }^{40} \mathrm{~K}$.

\section{MATERIALS AND METHODS}

\subsection{Study area}

The study area comprises the estuary of the Doce River and is located around the coordinates $19^{\circ} 37^{\prime} \mathrm{S}$ and $039^{\circ} 48^{\prime} \mathrm{W}$. According to Koppen classification, the local climate is of type "Aw" referring to hot and humid summer and dry winter. The Doce River delta is characterized by sandy and clay soils, as well as sediments including Cenozoic carbonaceous material existing in alluvial terraces dated from the Tertiary and Quaternary. Maximum precipitation occurs in December/January with a mean value of $244.4 \mathrm{~mm}$ and the minimum is in July with a mean value of $50.3 \mathrm{~mm}[6]$.

\subsection{Sampling and Preparation of Samples}

The collection of sediments was carried out manually, using rubber gloves, and with the use of decontaminated plastic utensils. The samples were placed in zip bags and identified. The sites on the Doce River were accessed by a motor boat. The collections were taken with water at a depth of approximately one (1) meter. After removing small fragments of gravel, the samples were 
dehydrated at $60^{\circ} \mathrm{C}$ in an oven for 24 hours, in disposable plastic petri dishes. No sieving procedure was applied to the sediments. After integration, samples were homogenized and placed in bottles of standard geometry for high resolution gamma spectrometry analysis in the low activity laboratory at the Metrology National Laboratory of Ionizing Radiation (LNMRI/IRD). The sediments and suspended materials in surface waters are often heterogeneous due to changes in small-scale hydrological regime and geo-morphological changes in the watershed. This variability can be minimized through the taking of a larger number of subsamples. The integration of subsamples was done because of these factors: (1) for better homogenization and (2) to fit the measurement standardization.

From a total of eleven (11) samples collected before and 11 collected after the rupture of the Fundão dam (before and after at same sites), five (5) representative subsamples with greater mass were blended to compose a single sample providing the a priori condition (as well as the "after" condition) -each one with $409 \mathrm{~g}$. For the gamma analysis method, sieve-dried samples were placed in plastic bottles of cylindrical shape with a diameter of $5.5 \mathrm{~cm}$ and a height of $10.0 \mathrm{~cm}$ [7]. Table 1 shows the geographical location of the sampling sites at the estuary. For each point presented here, sediment samples were collected during "before" condition on September 9th, 2014, and "after" on November 27th, 2015.

Table 1: Geographic location of samples collected in the estuary of Doce River (see Figure 2C).

\begin{tabular}{ccc}
\hline $\begin{array}{c}\text { Identification of } \\
\text { sampling points }\end{array}$ & Latitude & Longitude \\
\hline RD-1 & $19^{\circ} 33^{\prime} 32.64^{\prime \prime} \mathrm{S}$ & $39^{\circ} 50^{\prime} 25.76^{\prime \prime} \mathrm{W}$ \\
RD-2 & $19^{\circ} 34^{\prime} 27.64^{\prime \prime} \mathrm{S}$ & $39^{\circ} 48^{\prime} 42.60^{\prime \prime} \mathrm{W}$ \\
RD-3 & $19^{\circ} 35^{\prime} 13.28^{\prime \prime} \mathrm{S}$ & $39^{\circ} 47^{\prime} 51.60^{\prime \prime} \mathrm{W}$ \\
RD-4 & $19^{\circ} 36^{\prime} 43.68^{\prime \prime} \mathrm{S}$ & $39^{\circ} 48^{\prime} 36.90^{\prime \prime} \mathrm{W}$ \\
RD-5 & $19^{\circ} 37^{\prime} 10.29^{\prime \prime} \mathrm{S}$ & $39^{\circ} 48^{\prime} 45.54^{\prime \prime} \mathrm{W}$ \\
RD-6 & $19^{\circ} 37^{\prime} 29.91^{\prime \prime} \mathrm{S}$ & $39^{\circ} 48^{\prime} 50.27^{\prime \prime} \mathrm{W}$ \\
RD-7 & $19^{\circ} 37^{\prime} 48.29^{\prime \prime} \mathrm{S}$ & $39^{\circ} 49^{\prime} 1.47^{\prime \prime} \mathrm{W}$ \\
RD-8 & $19^{\circ} 38^{\prime} 28.94^{\prime \prime} \mathrm{S}$ & $39^{\circ} 48^{\prime} 34.84^{\prime \prime} \mathrm{W}$ \\
RD-9 & $19^{\circ} 38^{\prime} 29.30^{\prime \prime} \mathrm{S}$ & $39^{\circ} 48^{\prime} 48.44^{\prime \prime} \mathrm{W}$ \\
RD-10 & $19^{\circ} 39^{\prime} 13.96 " \mathrm{~S}$ & $39^{\circ} 48^{\prime} 56.94^{\prime \prime} \mathrm{W}$ \\
RD-11 & $19^{\circ} 39^{\prime} 5.36^{\prime \prime} \mathrm{S}$ & $39^{\circ} 48^{\prime} 49.90^{\prime \prime} \mathrm{W}$ \\
\hline
\end{tabular}




\subsection{Gamma-ray Spectrometry Analysis}

High-resolution gamma spectrometry is a highly accurate method for measuring the concentration of natural and anthropogenic radionuclides in the environment in general. The multielementary character and non-destructive gamma spectrometry characteristic makes it very useful in most environmental studies and, when required, rapid responses and wide spatial coverages [8]. In this study, the activity concentrations of ${ }^{228} \mathrm{Ra},{ }^{226} \mathrm{Ra}$ and ${ }^{40} \mathrm{~K}$ were investigated. In order to reach the radioactive equilibrium between ${ }^{226} \mathrm{Ra}$ and its decay products, samples were hermetically closed and stored for more than 30 days.

The measuring system was provided by CANBERRA and was composed of a hyper-pure germanium detector (HPGe) model GX4020 with a beryllium window, equipped with a preamplifier 2002CSL model, Cryostat 7500SL model-DRC-14 and an acquisition system of 1000 (Digital Spectrum Analyzer) that integrates the amplifier (ADC) and $5000 \mathrm{~V}$ high voltage source. The relative efficiency of the detector GX4020 is $40 \%$ and the resolution $\leq 2.00 \mathrm{keV}$ FWHM at $1332 \mathrm{keV}$ and $\leq 1.20 \mathrm{keV}$ at $122 \mathrm{keV}$. The energy ranges from $12 \mathrm{keV}$ to $3 \mathrm{MeV}$. The program used for the identification of the radionuclides and for the calculation of activities was "Gamma Acquisition \& Analysis" (GENIE 2000). For the data of disintegration of the radionuclides, the National Laboratory reference library Henri Becquerel (LNHB: http://www.nucleide.org/laraweb/) was used. Table 2 shows the radionuclides used in this study, their decay energies and also the probability of gamma ray emission with the uncertainty in parentheses.

Table 2 - Data of radionuclides of interest in this study.

\begin{tabular}{cccc}
\hline Radionuclides & Daughters products & $\begin{array}{c}\text { Energy } \\
(\mathbf{k e V})\end{array}$ & $\begin{array}{c}\text { Intensity } \\
(\boldsymbol{\%})\end{array}$ \\
\hline${ }^{{ }^{226} \mathbf{R a}}$ & ${ }^{214} \mathbf{B i}$ & 609.31 & $45.49(19)$ \\
& & 1120.29 & $14.91(3)$ \\
\hline${ }^{228} \mathbf{R a}$ & ${ }^{228} \mathbf{A c}$ & 338.32 & $11.40(41)$ \\
& & 911.2 & $26.20(8)$ \\
\hline${ }^{40} \mathbf{K}$ & \multirow{2}{*}{ direct analysis } & 1460.82 & $10.55(11)$ \\
\hline
\end{tabular}


For the construction of the efficiency curve, it was used a radioactive standard cocktail containing the following radionuclides and their activities: ${ }^{60} \mathrm{Co}(2002.243 \mathrm{~Bq}),{ }^{65} \mathrm{Zn}(2571.467$ $\mathrm{Bq}),{ }^{134} \mathrm{Cs}(2390.962 \mathrm{~Bq})$ and ${ }^{137} \mathrm{Cs}(2029.989 \mathrm{~Bq})$. These standards are certified by the LNMRIIRD / CNEN. The activities used in this standard were corrected to the date of the reference standard (Equation 1). Counting time was fixed to 60,000 seconds.

$$
\mathrm{A}=\mathrm{A}_{0} \mathrm{e}^{-\lambda \mathrm{t}}
$$

where $A$ is the radionuclide activity in $\mathrm{Bq} \cdot \mathrm{kg}^{-1} ; \mathrm{A}_{0}$ is the initial activity to the default; and, $\lambda$ is the decay constant of the radionuclide in the standard. After counting acquisitions, the specific activities were determined with Equation $2[9 ; 4 ; 10]$ :

$$
\mathrm{A}_{\mathrm{k}}\left(\mathrm{Bq} \cdot \mathrm{kg}^{-1}\right)=\frac{\mathrm{C}_{\text {liquidak }}}{\varepsilon_{\mathrm{k}} \cdot \mathrm{t} \cdot \mathrm{I}_{\mathrm{y}, \mathrm{k}} \cdot \mathrm{m}_{\mathrm{k}}}
$$

where, $\mathrm{C}_{\text {liquid,k }}$ is net count of the total area of the $k$-th photo peak of the radionuclide; $\epsilon_{k}$ is the efficiency of the detector related to the $k$-th radionuclide (obtained by the efficiency curve with the standard); $t$ is the counting time (s); $I_{y, k}$ is the gamma emission probability of the $k$-th radionuclide considered; $m_{k}$ is the mass of the sample $(\mathrm{kg})$. When the radionuclide of interest has two (2) or more gamma-rays, the final activity of the radionuclide is obtained as the weighted average of these energies.

\subsection{Aerogammaspectrometry}

Radionuclides of the natural series of ${ }^{232} \mathrm{Th},{ }^{238} \mathrm{U}$ and ${ }^{40} \mathrm{~K}$ present different chemical behaviors in the environment. Their concentrations depend on the geologic evolution to which they are associated and their concentrations typically differ according to the different types of rock, soil or sediment. This is due to the chemical and physical weathering that takes place during the formation and transformation of the rocks. In addition, the different elements produced in the radioactive chain have different solubility states and ultimately they are found in different equilibrium states. 
Because of these factors, the ratio among these radionuclides can be used to identify/differentiate geological formations [11]. For example, for the State of Rio de Janeiro, Brazil, the Quaternary sands and clays have mean activities of $56.94 \pm 37.87$ for ${ }^{238} \mathrm{U}$ (Bq.kg-1), $22.88 \pm 13.40$ for ${ }^{232} \mathrm{Th}\left(\mathrm{Bq} \cdot \mathrm{kg}^{-1}\right)$ and $215.8 \pm 182.4$ for ${ }^{40} \mathrm{~K}\left(\mathrm{~Bq} \cdot \mathrm{kg}^{-1}\right)$; for Granites and Proterozoic leucogranites, these values correspond to $83.43 \pm 43.41 ; 35.42 \pm 12.43$ and $449.9 \pm 261.4$, respectively [12]. Factors responsible for rock and sediment composition change depending on several physical and chemical weathering processes associated with wind, temperature gradients, surface oxidation and water percolation. The surface of mineral contact grains undergoes oxidation in contact with air and forms complexes in interstitial waters. These different forms of weathering combine to produce a spatial redistribution of radionuclides [13].

The Aerial Geophysics surveys, and in particular the mapping of aerogammaspectrometry, consist of a tool that makes it possible to determine, at high spatial resolution, the current state of radionuclide distribution. This allows inference of the environmental dose. In order to have a better view of the regional environmental dosimetry and investigate the validity of our dose models used, we have established a comparison of the sample results obtained for the Doce River with the mappings from the aerial geophysical survey. The aerogammaspectrometric survey for the region of interest (part of the State of Espírito Santo) was held during the years of 2009 and 2010. Levels were obtained from eTh, eU and $\mathrm{K}$ (eTh and eU are "equivalent" Th and $\mathrm{U}$ and represent an estimate of the concentrations of ${ }^{232} \mathrm{Th}$ and ${ }^{238} \mathrm{U}$ based on gamma emitters, Table 2, considering the radioactive equilibrium). We have built up a map of external absorbed dose from this data.

The aerogammaespectrometric survey refers to the Espírito Santo Geophysical Project performed by CPRM/Ministry of Defense with authorization numbers 896/09 and 897/09. Flights occurred between $5 / 9 / 2009$ and $1 / 18 / 2010$, totaling $124,236 \mathrm{~km}$ of profiles. The gamma spectrometer used was a Radiation Solutions model RS-500 with 1024 channels, coupled with an AG-NAV GPS with accuracy better than $10 \mathrm{~m}$. For the project, a total of 647.11 hours of flight was used. Flight lines were spaced $0.5 \mathrm{~km}$ apart and oriented in N/S direction. Flight height was $100 \pm 15 \mathrm{~m}$ above ground with approximately constant velocity at $270 \mathrm{~km} / \mathrm{h}$. The data acquisition interval was $1.0 \mathrm{~s}$. The upward and downward nuclear detecting systems were performed by 2 and $3 \mathrm{NaI}(\mathrm{Tl})$ large volume crystals, respectively. The energy ranges used were: eU (1.66-1.86 MeV), eTh (2.41-2.81 MeV) and ${ }^{40} \mathrm{~K}(1.37-1.57 \mathrm{MeV})$. The radionuclide survey is available at the Company of Brazil's Mineral 
Resources site: http://www.cprm.gov.br/. Maps are in scales of 1:100000 and 1:250000. Figure 2 summarizes the geological map of the region, the dose mapping and the delta of the Doce River indicating the sampling points according to Table 1. Data classification for the aerogammaspectrometric survey was carried out with the Software Idrisi GIS program 32 of Clark Labs [12].

Figure 2: (A) Geological domains around the Doce River; (B) a map of dose per aerogammaspectrometry on the frame $(A)$; and $(C)$ a map of dose to the region of the lower course and Doce River estuary in the State of Espírito Santo.

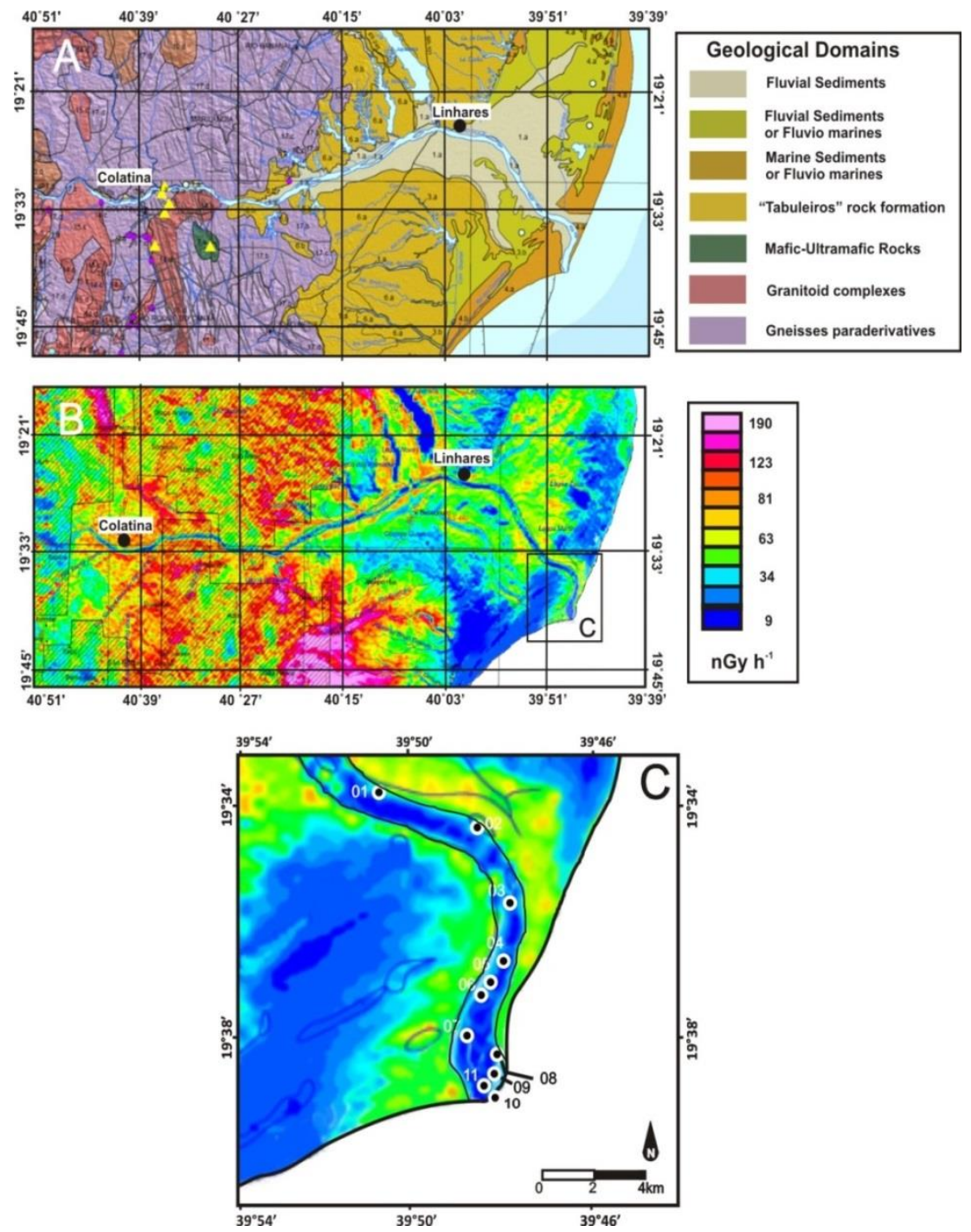




\subsection{Statistical analysis}

One of the important issues of this work is to compare the radiation levels of sediment samples to the periods before and after the rupture of the dam and to assess the radiological impact of the event at the study site. For the comparison of the samples' results, we used a hypothesis test, Student-t, for equality of means -assuming that data populations have unequal variances, as the samples (before and after) are of different characteristics, one being the natural river sediment and the second a highly contaminated sediment, that is, a mix of river material and mining tailings. For the comparison between the environment inferred from measured samples before and after, in the laboratory for ${ }^{232} \mathrm{Th},{ }^{238} \mathrm{U}$ and $40 \mathrm{~K}$, and those inferred by aerogammaspectrometry, considering the fact of lognormal distribution behavior of the data survey. Here we have conducted a KolmogorovSmirnov test to investigate the normality of the database. So, we built a confidence interval of $95 \%$ and compared with the doses obtained from the samples. We have used the approach proposed by Zhou and Gao [14] to build the lognormal confidence interval. From Figure 2C, the dose survey corresponded to 127,686 data points (each one corresponding to the pixels of the image). The data was classified and then we calculated the classified mean. We performed a transformation of the dose variable, $\mathrm{X}$, as $\mathrm{Y}=\mathrm{LnX}$. The average value obtained from the transformed variable was 3.30 and standard deviation, $\mathrm{S}$, was equal to 0.70 . The confidence interval is written as follows (where $\mathrm{z}$ $=1.96)$ :

$$
\bar{Y}+\frac{S^{2}}{2} \pm z \sqrt{\frac{S^{2}}{n}+\frac{S^{4}}{2(n-1)}}
$$

In this manner, we obtain the range 3.392 to 3.698. Performing the anti-logarithm of the defined variable as above we found $3.392=29.7 \mathrm{nGy} \cdot \mathrm{h}^{-1}$ and $3.698 \mathrm{nGy} \cdot \mathrm{h}^{-1}=40.4$, respectively.

\subsection{External gamma radiation dose}

The external gamma dose rate was calculated to the air, at $1 \mathrm{~m}$ above ground, and was estimated using Equation 4 [15; 16]:

$$
\dot{\boldsymbol{D}}=\left(0.427 A_{U}+0.662 A_{T h}+0.043 A_{K}\right)\left(n G y \cdot h^{-1}\right)
$$


where, $\dot{\mathbf{D}}\left(\mathrm{nGy} \cdot \mathrm{h}^{-1}\right)$ represents the absorbed dose rate in the air where only lithological sources were considered. Au, $\mathbf{A}_{\mathbf{T h}}$ and $\mathbf{A}_{\mathbf{K}}$ are activity concentrations in Bq.kg ${ }^{-1}$ for ${ }^{238} \mathrm{U},{ }^{232} \mathrm{Th}$ and ${ }^{40} \mathrm{~K}$, respectively.

\subsection{Activity concentration of Ra-equivalent (Raeq )}

An important parameter in environmental dosimetry or on radiological risk assessment is the radium equivalent activity $\left(\mathrm{Ra}_{\mathrm{eq}}\right)$. It can be calculated by Equation 5 and is based on the direct measurement of ${ }^{226} \mathrm{Ra}$ without using any short-lived decay product of uranium radioactive series:

$$
R a_{e q .}=A_{R a}+1.43 A_{T h}+0.077 A_{K}\left(B q . k^{-1}\right)
$$

where, ARa, A $\mathbf{A}$ and $\mathbf{A}_{\mathbf{K}}$ are the activities of ${ }^{226} \mathrm{Ra},{ }^{232} \mathrm{Th}$ and ${ }^{40} \mathrm{~K}$, respectively [17].

\subsection{External Radiological Risk Index}

The external radiological risk index is based on the premise that $370 \mathrm{~Bq} \cdot \mathrm{kg}^{-1}$ of ${ }^{226} \mathrm{Ra}$ or $259 \mathrm{~Bq}$ $\mathrm{kg}^{-1}$ of ${ }^{232} \mathrm{Th}$ or $4810 \mathrm{~Bq} \mathrm{~kg}-1$ of ${ }^{40} \mathrm{~K}$ will correspond to the dose limit of $1 \mathrm{mSv}$ for the public

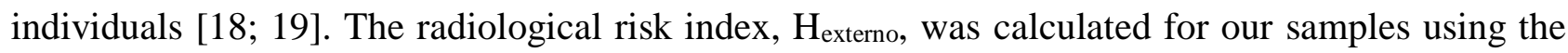
model proposed by [20]:

$$
H_{\text {external }}=\left[\left(A_{R a} / 370\right)+\left(A_{T h} / 259\right)+\left(A_{K} / 4810\right)\right] \leq 1
$$

Such a model has become an important indicator in the analysis of safety standards in radiation protection for public. Since the sand and sediment of the Doce River may, potentially, be used as construction material, the safe use of soils, sands and sediments should not exceed the reference level of $370 \mathrm{~Bq} \cdot \mathrm{kg}^{-1}$, according to the recommendations [21].

\subsection{Internal Radiological Risk Index}

Another index used here is the internal radiological risk, defined similarly to external radiological risk, and described by the model Equation 7. If the maximum activity of ${ }^{226} \mathrm{Ra}$ is half the acceptable limit, the $\mathrm{H}_{\text {internal, }}$ will be lower than the unit.

$$
\mathrm{H}_{\text {internal }}=\left[\left(A_{R a} / 185\right)+\left(A_{T h} / 259\right)+\left(A_{K} / 4810\right)\right] \leq 1
$$




\subsection{Annual Effective Dose Equivalent}

To estimate the annual effective dose, we should consider the absorbed dose conversion factor to the effective dose and the external occupancy factor, Equation 8. We will use the dose rate achieved for concentrations of natural radionuclides in sediments of the Doce River, adopting the conversion factor of $0.7 \mathrm{~Sv} \cdot \mathrm{Gy}^{-1}$ [16] of the absorbed dose in air to the effective dose received by adults and we will consider that a person passes, on average, $20 \%$ of the time away from home. The annual effective dose equivalent was calculated from equation [22]:

$$
\operatorname{AEDE}\left(\mu S v \cdot a^{-1}\right)=\left\{\dot { D } ( n G \dot { y } \cdot h ^ { - 1 } ) \left(8760\left(h \cdot a^{-1}\right)\left[0.2 x 0.7\left(S v \cdot G y^{-1}\right]\right\} 10^{-3}\right.\right.
$$

The occupational factor presented here is related to the estuarine area where the doses were calculated. The dose estimation is not valid for the entire affected river -for example, the river course where the population is agriculturally habit. For the estuarine area, the external exposure to the sediment containing taillings should only occur in the dry season when the river level reaches its minimum point, exposing its margins allowing transit, fishing and other activities. We adopted an occupational factor of 5 hours/day, 365 days/year, on average, as reasonably acceptable [23].

\subsection{Gonads Annual Dose Equivalent}

This parameter is a measure of genetic implication of the Annual Dose Equivalent in relation to the body with greater weight in human radiossensibility (gonads). The annual dose equivalent in these conditions to the gonads (AGDE) was calculated using the following formulation [22; 24]:

$$
A G D E\left(\mu S v \cdot a^{-1}\right)=3.09 \cdot A_{U}+4.18 \cdot A_{T h}+0.314 . A_{K}
$$

\section{RESULTS AND DISCUSSION}

The results of the activity concentrations with gamma spectrometry were achieved in this study for conditions before and after the presence of tailings in the estuary of Doce River. Based on the statistical methods presented in item 3.4, specific activities for ${ }^{228} \mathrm{Ra}$ and ${ }^{226} \mathrm{Ra}$ showed statistically significant differences at a 95\% confidence level, indicating increased values in environmental concentrations, in the case of ${ }^{40} \mathrm{~K}$, a reduction was observed. 
Table 3: Natural radionuclide activities, in $\mathrm{Bq}_{\mathrm{kg}}{ }^{-1}$, obtained before and after the rupture of Fundão dam at Doce River estuary.

\begin{tabular}{cccc}
\hline Condition & ${ }^{226} \mathbf{R a}$ & ${ }^{228} \mathbf{R a}$ & ${ }^{40} \mathbf{K}$ \\
\hline BEFORE & $15.86 \pm 0.99$ & $19.83 \pm 1.10$ & $237.15 \pm 8.70$ \\
AFTER & $20.70 \pm 0.99$ & $31.82 \pm 1.30$ & $197.50 \pm 7.62$ \\
\hline
\end{tabular}

On average, the concentrations after the breaking of the dam had increased $30 \%$ and $60 \%$ for the ${ }^{226} \mathrm{Ra},{ }^{228} \mathrm{Ra}$, respectively. For ${ }^{40} \mathrm{~K}$, the reduction was $17 \%$. The result for the "before" condition reflects the fluvial sediments in natural conditions, while for the "after" there was influence of the geological portions of the source area of the tailings, characterized by granites and gneisses. The result suggests that there was a significant transport of radionuclides contained in the waste. However, it is noteworthy that these results can be considered as relatively low compared to the world average values (35 Bq.kg-1 for ${ }^{238} \mathrm{U}, 35 \mathrm{~Bq} \cdot \mathrm{kg}^{-1}$ for ${ }^{232} \mathrm{Th}$ and $370 \mathrm{~Bq} \cdot \mathrm{kg}^{-1}$ to ${ }^{40} \mathrm{~K}$ ) for these radionuclides in sediments according to UNSCEAR [16]. Table 4 shows a comparison of this work with values of sediments found in other locations.

It is known that the transport of radionuclides from rivers to estuaries and their partitioning between dissolved and particulate phases are complex mechanisms and depend on interactions the physical, chemical and biological factors that occur in the aquatic environment. Anthropogenic inputs can also affect the distribution of radionuclides in this type of environment. Thus, a high variability in radionuclide activity in estuarine sediments is expected, as shown in the literature and synthesized in Table 4. From the extreme large sediment input during the "after" condition, it is absolutely true to declare that this value does not represent any possible natural variability condition for the sedimentary load. An illustration is depicted in Figure 4, two satellite images at a site near the estuary, where the river condition before and after the tailing apportionment is shown side by side. Also, a change was made to the texture of samples "before" and "after" in order to contrast a part of the natural regime of sedimentary variability. The samples "after" are reddish as opposed to the typical brown-to-green colors of the "before" samples. 
Table 4: Comparison of the sample activities (Bq. $\mathrm{kg}^{-1}$ ) from Doce River estuary, with values for other locations.

\begin{tabular}{|c|c|c|c|c|c|c|}
\hline Country & $\begin{array}{l}\text { Sample } \\
\text { type }^{1}\end{array}$ & $\begin{array}{l}\text { Sources } \\
\text { Activity }^{2}\end{array}$ & ${ }^{238} \mathbf{U}$ & ${ }^{232} \mathrm{Th}$ & ${ }^{40} \mathrm{~K}$ & Reference \\
\hline Albania & Sedsea & Agric & $0-27$ & $13-40$ & $266-675$ & Tsabaris (2007), [25] \\
\hline Algeria & Sedsea & Ind & $11-25$ & $6-32$ & $56-607$ & Benamar (1997), [26] \\
\hline Belgium & Soil & Env & " - " & $9-47$ & $170-610$ & Deworn (1988), [27] \\
\hline China & Soil & Ind & $26-119$ & $35-228$ & $281-711$ & Ziqiang (1988), [28] \\
\hline Spain & Sedsea & Ind & " - " & $11-16$ & $220-460$ & Ligero (2001), [29] \\
\hline Egypt & Sedsea & Ind & " - " & $8-50$ & $16-487$ & Ibrahiem (1995), [30] \\
\hline France & Sedriver & Ind & $9-62$ & $16-55$ & $120-1026$ & Lambrechts (1992),[31] \\
\hline Greece & Soil & Env & $29-110$ & $19-88$ & $152-1593$ & Florou (1992), [32] \\
\hline Greece & Soil & Env & $15-1049$ & $18-66$ & $258-2464$ & Travidon (1996), [33] \\
\hline Netherlands & Soil & Env & $19-47$ & $22-77$ & $290-700$ & Koster (1988), [34] \\
\hline Ireland & Soil & Env & $8-120$ & $3-60$ & $40-800$ & McAuley (1988), [35] \\
\hline Italy & Soil & Ind & " - " & $16-62$ & $398-649$ & Buttaglia (1988), [36] \\
\hline Japan & Soil & Mine & " - " & $5-185$ & $75-1400$ & Megumi (1988), [37] \\
\hline Turkey (Firtina) & Sedriver & Ind & $16-113$ & $17-87$ & $51-1605$ & Kurnaz (2007), [22] \\
\hline Saudi Arabia & Sedsea & Ind & 11.68 & 6.21 & 169.40 & El-Taher (2018), [38] \\
\hline Brazil (Rio Doce ${ }_{\mathrm{B}}$ ) & Sedriver & Mine & 15.86 & 19.83 & 237.15 & Present study \\
\hline Brazil (Rio Doce ${ }_{\mathrm{A}}$ ) & Sedriver & Mine & 20.7 & 31.82 & 197.15 & Present study \\
\hline
\end{tabular}

$\mathbf{1}-$ Sedsea $=$ Sea sediment Sedriver $=$ River sediment.

$\mathbf{2}-$ Agric $=$ Agriculture; Ind $=$ Industrial $;$ Env $=$ Environment radioactivity 
Figure 3: Site near the estuary of Doce River "before" (brown-to-green color) and "after" (reddish).

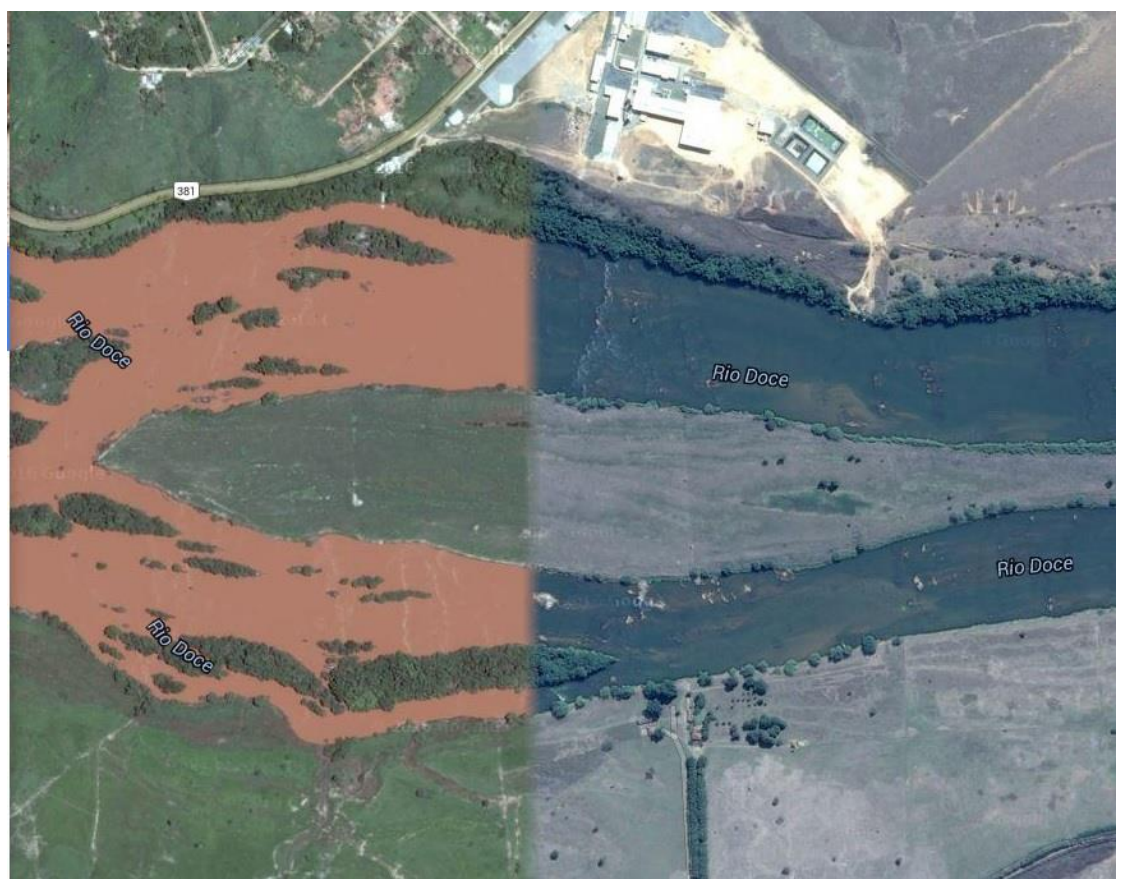

From a global perspective, the increase for ${ }^{238} \mathrm{U}$, in Table 4 , do not represent an outsider value. If we consider the median point values for Albania, Algeria and France, one may observe that the results of this study are consistent with those values, while for China, Greece, Holland, Ireland and Turkey, our values for both conditions are well below those reports. For the ${ }^{232} \mathrm{Th}$, considering the mean values of the surveys carried out in Albania, Algeria, Belgium, France, Ireland, Italy and Egypt, our values are equivalents to those countries while in comparison to Spain, the Doce River is relatively higher. Comparisons with the Netherlands, Greece, Turkey, Japan and China show that our values are lower. For ${ }^{226} \mathrm{Ra}$ activity, our value for "before" condition is greater than the midpoints of Albania, Belgium, Spain, Egypt, France and Greece and equivalent to the midpoint range of Japan and Turkey. The value found for "after" condition is compatible with values in Ireland and well lower than reported for Italy.

From the activities of radionuclides in Table 3, it was possible to make estimates of radiological parameters which are summarized in Table 5. 
Table 5: Radiological parameters related to sediment radionuclide compositions in Doce River.

\begin{tabular}{|c|c|c|c|c|c|c|}
\hline $\begin{array}{c}\begin{array}{c}\text { River } \\
\text { condition }\end{array} \\
\text { B/A } \\
\end{array}$ & $\begin{array}{c}\dot{\mathbf{D}} \\
\left(\mathbf{n G y} \cdot \mathbf{h}^{-1}\right)\end{array}$ & $\begin{array}{c}\mathbf{R a}_{\mathrm{eq}} \\
\left(\mathbf{B q} \cdot \mathrm{kg}^{-1}\right)\end{array}$ & $\mathbf{H}_{\text {externo }}$ & $\mathbf{H}_{\text {interno }}$ & 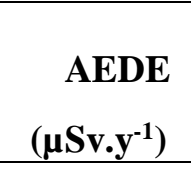 & $\begin{array}{c}\text { AGDE } \\
\left(\boldsymbol{\mu S v} \cdot \mathbf{y}^{-1}\right)\end{array}$ \\
\hline BEFORE & $30.1 \pm 0.9$ & $62.5 \pm 2.0$ & $0.17 \pm 0.01$ & $0.21 \pm 0.01$ & $36.9 \pm 0.92$ & $206.4 \pm 6.7$ \\
\hline AFTER & $38.4 \pm 1.0$ & $81.4 \pm 2.2$ & $0.22 \pm 0.01$ & $0.28 \pm 0.01$ & $47.1 \pm 0.99$ & $259.0 \pm 4.3$ \\
\hline
\end{tabular}

The confidence interval for the absorbed dose determined by the aerogammaspectrometry, Figure 2C, ranged from $29.7 \mathrm{nGy} \cdot \mathrm{h}^{-1}$ to $40.4 \mathrm{nGy} \cdot \mathrm{h}^{-1}$. Based on Equation 4, our doses' values, obtained from samples, for before and after varied from 30.1 and $38.4 \mathrm{nGy} \cdot \mathrm{h}^{-1}$, which means that both estimates from laboratory measurements do represent the regional context of the geology. Through these results, it can be observed that the doses for before and after the accident are below the internationally recommended dose rate of $55 \mathrm{nGy}^{-1} \mathrm{~h}^{-1}$ [39]. The results for the annual effective dose equivalent were of 36.91 and $47.08 \mu \mathrm{Sv}^{-\mathrm{y}^{-1}}$ for before and after, respectively, while the world average is $70 \mu \mathrm{Sv} \cdot \mathrm{y}^{-1}[16]$.

The radium equivalent activities before and after were both values below the safety limit recommended (370 Bq. $\mathrm{kg}^{-1}$ ). This means that the external gamma dose rate of this study is at least $30 \%$ lower than that published [17]. 
Figure 4 - Dose distribution from aerogammaspectrometric survey, Figure 2C. At the top, the lognormal confidence interval is indicated. The vertical dashed lines show the dose values before and after the rupture of the dam, obtained by analysis of sediment samples. The solid line is a polynomial adjustement applied to the distribution of doses.

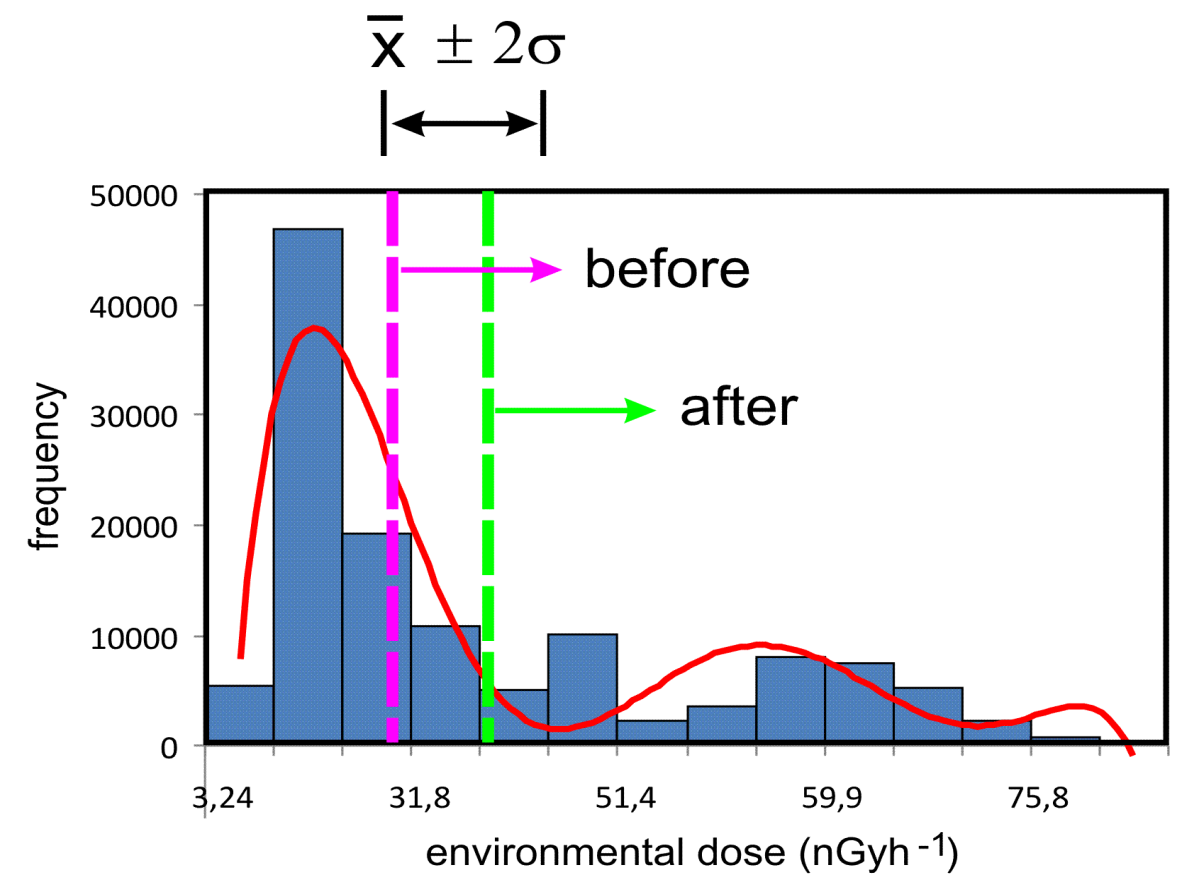

In the case of the annual dose equivalent in the gonads (AGDE), 206.4 and $259.0 \mu$ Sv. $^{-1}$ were obtained for before and after, respectively. These data, compared to the world average of $300 \mu \mathrm{Sv}^{-\mathrm{y}^{-}}$ ${ }^{1}$ show that our results are $31.2 \%$ and $13.7 \%$ lower than the world average, which must be evaluated carefully and suggest further monitoring of the post-disaster conditions.

\section{CONCLUSION}

This study evaluated the activity concentrations of ${ }^{232} \mathrm{Th},{ }^{226} \mathrm{Ra}$ and ${ }^{40} \mathrm{~K}$ for 11 sediment samples collected in the Doce River estuary, in conditions before and after the arrival of Samarco S.A. mining waste. Mean concentrations of these radionuclides, despite the increase approximately $50 \%$ during after condition, are within ranges of activity reported in current literature. Our data of absorbed dose obtained from sediment samples were comparable to those estimated by 
aerogammaspectrometry, which reinforce the ability of the aerogamma surveys to map the natural radioactivity levels.

For "before" and "after"conditions, the values obtained for Dं varied from 30.1 to $38.4 \mathrm{nGy} \cdot \mathrm{h}^{-1}$,

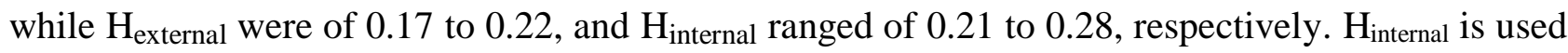
for calculus due to inhalation of radon and toronium in homes. Its use would not make sense for an outdoor environment. Due to the possibility of the use of sediments and sand as building material for residences, the calculation of this index may be an estimator for the risk arising from the inhalation of radon and toronium by the locals. However, considering that the population inhabits the region only during the dry season, the occupation factor would decrease from 365 days / year to 152 days / year. Thus, the calculated doses would be reduced by a factor of 5/12 of the presented value.

The dose equivalent annual gonads (AGDE) were of 206.4 and $259.0 \mu \mathrm{Sv}^{-\mathrm{a}^{-1}}$. Considering the world average of $300 \mu \mathrm{Sv}^{-\mathrm{a}^{-1}}$, the post disaster condition is slightly lower than the world average but cannot be neglected. Anyway all parameters are below of the reference levels.

The annual effective dose equivalent considering the conditions for before $\left(36.9 \mu \mathrm{Sv}_{\mathrm{a}} \mathrm{a}^{-1}\right)$ and after $\left(47.1 \mu \mathrm{Sv} \cdot \mathrm{a}^{-1}\right)$ are lower than the world average $\left(70 \mu \mathrm{Sv} \mathrm{a}^{-1}\right)$ and the associated risk to health is not significant. This does not rule out the importance of other routes of contamination, and corresponding doses and risks, which must be investigated and were not the focus of this contribution. Therefore, the values estimated in this paper can be used as baseline for future investigations.

\section{ACKNOWLEDGMENTS}

The authors would like to thank the LNMRI/IRD, LARAMG/UERJ and LBBA/UFES for assistance in sampling and sample count of Doce River and the CPRM for providing the database of $\mathrm{U}$, Th, and $\mathrm{K}$ that summarizes the geological map of the region mapping of dose and the lower course of the river. 


\section{REFERENCES}

[1] JONES, D., 2004. The relative importance of physical, chemical and biological processes in the Irish sea. Earthwise Issue 21. British Geological Survey. NERC 2004.

[2] GIGLIO, V.J. \& FREITAS, M.O. Caracterização da pesca artesanal com rede de camboa na reserva extrativista de Cassurubá-BA, Bitemas. 26(2), (2013), 249-259.

[3] ICMBio, Instituto Chico Mendes da Biodiversidade - Relatório Consolidado da Pluma do Rio Doce após Rompimento da Barragem de Mariana-MG, Universidade Federal do Espírito Santo (UFES), 2017, pp.254.

[4] DELGADO, J.U., CARVALHO, J.L.S., TAUHATA, L. Use of multivariate and neutron activation analysis on studying element interrelationships in Brazilian phosphorite. Journal of Radioanalytical and Nuclear Chemistry v. 173(1), 179-184, 1993.

[5] DAVIS, J., 2004. Naturally Ocurring Radioactive Materials. Earthwise Issue 21. British Geological Survey. NERC 2004.

[6] IBGE, Instituto Brasileiro de Geografia e Estatística. Anuário Estatístico do Brasil-Rio de Janeiro, Vol. 56, 1996.

[7] IAEA, International Atomic Energy Agency. Collection and preparation of bottom sediment samples for analysis of radionuclides and trace elements. TECDOC 1360 (2003), 130p.

[8] RAMOS-LERATE, I., BARRERA, M., LIGERO, R.A., CASAS-RUIZ, M. Use of Gamma Radionuclides as Tracers to Investigate Transport of Sediments in the Bay of Cádiz. Applied Sciences and the Environment. Vol. 23 (1998), 217-229.

[9] CARNEIRO, P.F.P., FILHO J., SILVA, C.M. Environmental Radioactivity on Suape Estuary: Impact of the Installation of Oil Refinary. International Nuclear Atlantic Conference - INAC 2009.

[10] DLUGOSZ-LISIECKA, M.\&BEM, H. Fast procedure for self-absorption correction for low $\gamma$ energy radionuclide $210 \mathrm{~Pb}$ determination in solid environmental samples. J. Radioanal. Nucl. Chem 298 (2013) 495-499.

[11] WOLLEMBERG, H.A. E SMITH, A.R. A Geochemical Assessment of Terrestrial Gamma-ray Absorbed Dose Rates. Health Physics, 1990. 
[12] LICÍNIO, M.V.S., 2002. Radioatividade Ambiental no Estado do Rio de Janeiro: Dosimetria Externa e Correlações com Parâmetros Geoambientais e Urbanísticos. Dissertação de Mestrado em Biologia (Biociências Nucleares). Universidade do Estado do Rio de Janeiro (UERJ), pp. 94. [13] LEINZ, V. E AMARAL, S.E. Geologia Geral, Vol.1- Companhia Editora Nacional, 2001.

[14] ZHOU, X-H., AND GAO, S. Confidence intervals for the log-normal mean. Statistics in Medicine, 16, 783-790, 1997.

[15] BECK, H.L. The physics of environmental radiation fields. Natural radiation environment II. CONF-720805 P2. Proceedings of the Second International Symposium on Natural Radiation Environment, 1972.

[16] UNSCEAR, United Nations Scientific Committee on the Effects of Atomic Radiation. Sources, Effects and Risks of Ionizing Radiation. Report to the General Assembly with Annex B, United Nations, New York, 2000.

[17] BERETKA, J., MATHEW. P.J. Natural radioactivity of Australian building materials, industrial wastes and by products. Health Phys. 48 (1985),87-95.

[18] UNSCEAR, United Nations Scientific Committee on the Effects of Atomic Radiation. Sources, Effects and Risks of Ionizing Radiation. Report to the General Assembly with Annexes, United Nations, New York, 1977.

[19] SROOR, A., EL-BANI, S.M.,AHMED, F., ABDEL-HALEEN, A.S. Natural radioactivity and radon exhalation rate of soil in southern Egypt. Appl. Radiat. Isot. 55 (2001), 873-879.

[20] KRIEGER, R. Radioactivity of construction materials. Betonwerk Fertigteil-Tech 47 (1981), 468.

[21] HASSAN N.M. , ISHIKAWA T., HOSODA M., SORIMACHI A., TOKONAMI S., FUKUSHI M. e SAHOO S.K., 2010. Assessment of the natural radioactivity using two techniques for the measurement of radionuclide concentration in building materials used in Japan, J Radioanal Nucl Chem, v. 283 p. 15-21.

[22] KURNAZ, A., KÜCÜKÖMEROGLU, B., KESER, R., OKUMOSOGLU, N.T., KORKMAZ, F., KAHARAN, G., ÇEVIK, U. Determination of radioactivity levels and hazards of soils and sediment samples in Firtina Valley (Rize, Turkey). Appl. Radiat. Isot. 65 (2007), 1281-1289. 
[23] MELLO, C.R.; VIOLA, M. R.; CURI, N.; SILVA, A.M.. 2012. Distribuição espacial da precipitação e da erosividade da chuva mensal e anual no Estado do Espírito Santo. Rev. Bras. Ciênc. Solo vol36(6): 1878-1891.

[24] RAVISANKAR, R., SIVAKUMAR, S., CHANDRAKARAN, A., JEBAKUMAR, J.P.P., VIJAYALAKSHAMI, I., VIJAYAGOPAL, P., VENKATRAMAN, B. Spatial distribution of gamma radioactivity levels and radiological hazard indices in the East Coastal sediments of Tmilnadu, India withi statistical approach. Radiation Physics and Chemistry 103 (2014), 89-98.

[25] TSABARIS, C., ELEFTHERIOU, G., KAPSIMALIS, V., ANAGNOSTOU, C., VLASTOU, R., DURMICHI, C., KEDHI, M., KALFAS, C.A., 2007. Radioactivity levels of recent sediments in the Butrint Lagoon and the adjacent cost of Albania. Appl. Radiat. Isot. 65 (4), 445-453.

[26] BENAMAR, M.A., ZERROUKI, A., IDIRI, Z., TOBBECHE, S., 1997. Natural and artificial levels in sediments in Algiers Bay. Appl. Radiat. Isot. 48 (8), 1161-1164.

[27] DEWORN, JP., SLEGERS, W., GILLARD, J., FLIEMAL, J.M., CULST, J.P. Survey of the natural radiation of Belgium territory as determined by different methods. Radiation Protection Dosimetry 24 (1/4), 347-351, 1988.

[28] ZIQIANG, P., YIN, Y., MINGQIANG, G. National Radiation and radioactivity in China. Radiation Protection Dosimetry 24 (1/4), 29-38, 1988.

[29] LIGERO, R.A., RAMOS-LERATE, I., BARRERA, M., CASAS-RUIZ, M., 2001. Relationships between seabed radionuclide activities and some sedimentological variables. J. Environ. Radioact. 57, 7-19.

[30] IBRAHIEM, N.M., SHAWKY, S.M., AMER, H.A., 1995. Radioactivity levels in Lake Nasser sediments. Appl. Radiat. Isot. 46 (5), 297-299.

[31] LAMBRECHTS, A., FOULQUIER, L., GARNIER-LAPLACE, J., 1992. Natural Radioactivity of the main French rivers. Radiat. Prot. Dosim. 45(1), 253-256.

[32] FLOROU, H., KRIDITIS, P., 1992. Gamma radiation measurements and dose rate in the coastal areas of a volcanic island, Aegan Sea, Greece. Radiat. Prot. Dosim. 45(1), 277-279.

[33] TRAVIDON, G., FlOURO, H., ANGElOPOUlOS, A., SAKELLIOU, L. Environmental study of the radioactivity of the Spas in the Island of Ikaria. Greece. Radiation Protection Dosimetry $63(1), 63-67,1996$. 
[34] KOSTER, H.W., KEEN, A., PENNDERS, R.M.J., BANNINK, D.W., DE WINKEL, J.H. Linear regression models for the natural radioactivity (238U, 232Th and 40K) in Dutch soil: a key to anomalies. Radiation Protection Dosimetry 24 (1/4), 63-68, 1988.

[35] MCAULKAY, I.R., MORAN, D. Natural radioactivity in soil in the Republic of Ireland. Radiation Protection Dosimetry 24 (1/4), 47-49, 1988.

[36] BUTTAGLIA, A., BRAMATI, L. Environmental radiation survey around a coal-fired power plant site. Radiation Protection Dosimetry 24 (1/4), 407-410, 1988.

[37] MEGUMi, K., OKA, T., DOI, M., KinURA, S., TSUJimOTO, T., ISHIYAMA, T., KATSURAYAMA, K. Relationships between the concentrations of natural radionuclides and mineral composition of the surface soil. Radiation Protection Dosimetry 24 (1/4), 69-72, 1988.

[38] EL-TAHER, A., ALSHAHRI, F., ELSAMAN, R., 2018. Environmental impacts of heavy metals, rare earth elements and natural radionuclides in marine sediment from Ras Tanura, Saudi Arabia along the Arabian Gulf. App. Radiat. Isot. 132, 95-104.

[39] UNSCEAR, United Nations Scientific Committee on the Effects of Atomic Radiation, 1988. Exposures from natural sources of radiation. Report to the General Assembly, U.N., New York, USA. 